Živković Aleksandar ${ }^{1}$

University of Belgrade, Faculty of Economics

Kristijan Ristić ${ }^{2}$

University Union - Nikola Tesla, Belgrade,

Bussines and law faculty
SCIENTIFIC REVIEW ARTICLE doi:10.5937/ekonomika1904053Z

Received: September 04. 2019.

Accepted: October 14. 2019.

\title{
ANALYSIS OF THE FUNCTIONAL DOMAIN OF DOCTRINAL APPROACHES IN MONETARY THEORY AND POLICY
}

\begin{abstract}
The genesis and development of economic and financial thought are characterized by the past and yet still ongoing struggle and confrontation between monetarists and Keynesians, their mutual polarization, and the long-standing debate "for and against" new theories, which has demonstrated that theoretical and analytical disagreements essentially do not exist, especially not between the leading monetarists and keynesians. The opposing theses "money is not important" and "only the money is important" have been transmitted, after a decade of theoretical and empirical testing, into the official common thesis that "money is important". In this paper, using the desk research method, we start from an aspiration to present the genesis of these different approaches, however avoiding to reduce it to the synthesis of approaches, but rather striving to point to valuable contribution of such polemics in order to reconsider global tendencies in implementing monetary and general macroeconomic policies. In generic terms, the ongoing global financial crisis has justified the validity of such reconsiderations, since monetary and fiscal policies are the most suitable instruments for macroeconomic policy of growth management.
\end{abstract}

Key words: monetary theory, money, economic policy, growth.

JEL classification: G 32, E44, E52.

\section{АНАЛИЗА ФУНКЦИОНАЛНОГ ДОМЕТА ДОКТРИНСКИХ ПРИСТУПА У МОНЕТАРНОЈ ТЕОРИЈИ И ПОЛИТИЦИ}

\begin{abstract}
Апстракт
Генезу и развој економске и финансијске мисли карактерише некадашть а и данас врло актуелна борба и конфронтација монетариста и кејнзијанаца, юихова међусобна поларизација те и дугогодинна дебата „за и против” нових теорија, чиме се показало да теоријска и аналитичка неслагана у суштини не постоје, нарочито између водећих монетариста и кејнзијанаца. Супротставъене тезе „новаи, није важан” и „само је новаи, важан” преточене су, након деценијског те-
\end{abstract}

\footnotetext{
${ }^{1}$ aca@ekof.ac.bg.rs

${ }^{2}$ kristijanristic.fpim@yahoo.com
} 
оријског провераваюа и емпиријског тестираға, у „официјелну заједничку тезу“ „новаи јесте важан“. У овом раду, користеии се методом деск истразивань потазимо од тезне да, приказујуии генезу разлииитих приступа, исте не сводимо на юихову синтезу веи, утврђујемо допринос оваквих полемика у ииту преиспитивана глобалних тенденција у вођену монетарне и генерално макроекономске политике. Генерички посмтарано и актуелна светска финансијска криза утемелила је валидност оваквих преиспитиваға јер су монетарна и фискална политика најпогоднији инструменти макроекономске политике управљаньа растом.

Кључне речи: монетарна терија, новаи, економски политика, раст.

\section{Introduction}

The monetarist and Keynesian system is very difficult to present in the form of a catalogue of relatively accepted theses, because the spectre of Keynesian doctrine is wide, rather diffused and more prevalent in the earlier economic theory and research. Unlike monetarists, who find the changes in money supply to be the most important determinant of change in nominal income, in Keynesian doctrine no dominant macroeconomic size can be found for determining the general price level. Most Keynesians do not think that the money supply is of no significance for the movement of a general price level, just as most monetarists do not believe that money is the sole determinant of changes in nominal income, or the value of money. The key difference between monetarists and Keynesians is, however, that monetarists claim that the general price level is a macroeconomically determined size, while Keynesians find that the total price level is derived from individual prices, which are determined by the level of wages, increasing profits, tax level, progress in production and prices of imported goods. Formation and use of income represent the key points in the process of individual prices deriving from general level of prices, because incomes are the basis of monetary demand and a component that is included in supply prices as a cost factor or an increase in profit. The increase in profit, as a rule, serves to increase additional investments, and consequently increase demand, while the increase in wages serves to increase demand in consumer goods. Progress in production strives to reduce costs and increase productivity, and the change in tax rates correlates with predefined public sector expenditures (direction of which is often countercyclical). The Keynesian thesis on the microeconomic determination of the general price level incorporates the assumption that the change in individual prices affecting the level of prices is not compensated with opposite movements. In this context, the Keynesians assume (1) that the money supply is elastic (i.e. it does not represent a factor of restriction in the economy) and (2) that the restrictive character in the case of insufficient elasticity of the money supply primarily impacts the direction of decline in production and employment. (Cencini, 1997; Brunner and Meltzer, 1997)

The thesis on the endogeny of money supply, represented by Keynesians, derives from the banking theory. However, modern monetary economies rely on several components in their mechanisms of money creation (refinancing component, externaleco-component component and fiscal component), in which the central bank, commercial 
banks and non-banking sectors participate. The thesis on the endogenous character of the money supply, as a rule, comes to attention in systems in which central banks are unable to influence the increase in wages, which, rather than increasing the productivity of labour, induce an increase in prices. Commercial banks are forced to make available additional loans to companies to finance the increase in wages. Also, experience suggests that central banks, in times of stagnation of economic growth or recession, have been forced to obtain liquidity for commercial banks and companies in order to create the preconditions for the economic growth revival. (Cencini, 1997)

Monetarists interpret the stability of money demand as "the stable function of a finite number of variables that illustrate it", while Keynesians, due to their belief in the instability of money demand, are focusing on the fluctuations in the velocity of money circulation that are noticeable in conjunctural trends. Keynesians, from their concept of the instability of demand for money in a conjuncture, derive the need for an anti-cyclical monetary policy. Monetarists, however, from their concept on the stability of money demand, generate monetarist "beliefs" in linking money supply to "rules of the game" in order to mitigate conjunctural fluctuations. As a rule, monetarists explain the thesis on the stability of the private sector by empirical researches of money, prices, production, and income, the results of which show a parallelism between the movement of money and nominal income. Therefore, the monetarist thesis of stability, or the Keynesian thesis of instability, both have two aspects: (1) the aspect of stability, that is, the instability of money demand that is considered within the transmission process, and (2) the aspect of stability, or the instability of the economic sector, which is considered from the point of view of demand. ${ }^{3}$ (Ristic, Zivkovic, 1998)

\section{Overview of macroeconomic literature in light of differentiating approaches in monetary theory}

Analysing the development of macroeconomic theory through a paradigm of interest theory development, Leijonhufvud points out that the principle of "saving is investing" was dominant until Friedman revived the quantitative theory of money. Therefore, the difference between Keynesian and monetary advocates lies solely in the assessment of whether the interest rate can coordinate savings and investments, and thus the level of economic activity. (Brunner, 1968; Friedman, 1972; Mayer, 1978)

Following the neo-Keynesian stances, Tobin has pointed out that the primary cause of declining production, productivity and employment, stagflation lies in the reduced attractiveness of investment. Tobin, as a theorist of money, conjuncture, production, employment, prices, financial markets and transmission mechanism, destroys the weak points of monetarism, i.e. the thesis about the inherent stability of the economic sector (which, after every disorder, from the outside or from the inside, in itself, regains its balance with full employment), the thesis of the exclusive monetary phenomenon of inflation (the causes of which are always excessive multiplication of money) and the thesis of strict control of growth of money supply (which, when stabilized, automatically contributes to the stabilization of prices) from the point of view of catastrophic economic-

${ }^{3}$ Adapted form from citated literatyre. 
social consequences of a one-sided monetarist anti-inflation policy. Tobin, therefore, advocates the formulation of a modern policy of conjuncture, which, along with monetary suppression of inflation and income policy, would consistently and systematically suppress the development of income, along with the aggregate demand (boosted by inflation). The essence of the harmonized program is reflected in the simultaneous suppression of inflation and unemployment and the promotion of growth. (Tobin, 1972)

The nominal interest rate can deviate from the natural one only if the amount of money increases so much as to disrupt its "neutrality". In Hayek's opinion, banks are responsible for such movements, because if the nominal interest rate is below the natural one, there is a surplus of investments that can be settled only by reducing the level of production and employment until the natural and nominal interest rate is equalized. But if the natural interest rate is expressed in commodity, not in money, as Sraffa thinks, there will be as many natural interest rates as there are goods. And if, however, there is no natural level of interest rates, there will be no neutral amount of money, which means that Hayek's theory of business cycles, according to Sraffa, was wrong. (as Tobin interpreted, 1972) ${ }^{4}$

The revival of neoliberalism, the rise of monetarism and the crisis of the state of prosper have led to the emergence of a special synthesis of the neo-Keynesian doctrine and the monetarist paradigm into so-called structuralism (and the new industrial state), whose liberal-conservative measures correspond to capital and capital-wise relation.

Theory of the so-called supply economy, by its constituent elements, is closer to monetarist theory than to Keynesian theory, although it incorporates certain fiscal elements. The "Supply-Side Economics" theory is born as a reaction to the traditional macroeconomic policy that relies on demand. Disappointment in the dilemma of demand theorists: less inflation - more unemployment (monetarists) or less unemployment - more inflation (Keynesians) has contributed to an accelerated resurrection of the theory of supply and the arrival of structuralists. (Ristic, Zivkovic, 1998) The supply theory based on the microeconomic approach advocate to increase profits, savings and investments (in the conditions of eliminating uncontrolled socialization of income and imposed state regulation), and to reduce unemployment by growth in production. (Ibidem)

Only in the short term, it is necessary to provide realistic preconditions for economic growth by removing the installed inflationary disturbances, whereas in the long term we should strive for increased production and reduction of unemployment. A restrictive monetary policy, in this context, would aim only to curb the inflation rate. The monetary tightening (determining the rising interest rate trend) must yield the expected results in terms of the deceleration of the growth rate of the general price level, even with the relatively high price of the recession. For only recession-induced purification can break down the rigidity of wages and change the functioning of the labour market. (Tobin, 1972; Ristic, Zivkovic, 1998)

Monetarism, therefore, is not a monolithic and homogeneous block, but a school with convergent and divergent stances and common fundamental elements. Namely, the common elements of the monetarist propositions consist in the following: (1) the monetary factor has a determining effect, that is, variations of the monetary mass have a dominant influence on the evolution of the level of nominal national income, (2) the

${ }^{4}$ More in monetary elaboracion, Smithin, 2003. 
private sector is inherently stable, and perturbations in the level of economic activity results from the shock caused by the growth of the monetary mass, and (3) there is no relation between inflation and unemployment in the long term (as indicated by the longterm vertical Phillips curve), because the perfectly anticipated inflation has no effect on the level of unemployment, which has already been "placed" in an equilibrium position under the hypothesis of the so-called " rates of natural unemployment. Beyond these propositions, significant differences are revealed between the variations of monetarism with different implications for economic policy (Barton), although Brunner, Mayer, Vanne, Thompson and Friedman claim that there are other common elements in monetary variants. ((Brunner, 1968; Friedman, 1972; Mayer, 1978, Ristic \& Zivkovic, 1998, Zivkovic \& Lakic \& Ristic, 2019)

The monetarist credo rests basically on two hypotheses: first - inflation results from uncontrolled expansion and fluctuation of money, and, second, the expansion of money supply can be controlled by raising the level of interest rates, tightening the lending policy and managing reserves. Since there is a close connection between reserves and monetary goods, in implementing the rules of constant growth of money supply, reserves represent an essential instrument of monetary policy. However, while observing the monetary policy of the United States, we find the argues that it is wrong to prescribe its failure to their monetary authorities being indecisive whether to achieve quantitative targets for primary emissions, or to achieve interest rate targets. In support of this, in contemporary conditions the central authorities do not have absolute control over the emission of primary money and that the fluctuations between the amount of primary money and money supply are contrary to the one argued by the monetarists. In the context of function of the monetary fund reaction tested in the IS-LM model, the results show that the recent large increase in the amount of primary money can be ascribed to the increase in government debt, while the increase in the amount of primary money is due to higher inflationary expectations and earlier increases in the amount of primary money. Therefore, the argument that the effect of money on nominal income refers to the real income, rather than to the price component, constitutes a Keynesian alternative to a monetarist position. (Brunner, 1968; Friedman, 1972; Tobin, 1972; Mayer, 1978)

\section{Evolution of monetary theory and reflecting on monetary analysis of today}

in the evolution of monetary theory, periodization is commonplace, which facilitates the creating of roads and development of thought from the point of view of theoretical rights, time horizons and spatial location. Namely, in the monetarist economics literature, the following phases of the development of monetarist theory have emerged: (1) the period of classical and neoclassical quantitative money theory, which ruled until the mid-1930s (2), the period of the Keynesian revolution in the form of Keynesian income monetarist theory (with the emergence of "General Theory"), the differentiation of Keynesian theory with the tendency of neoclassical synthesis and the emergence of monetarist theory of property approach, which became important especially since the mid-1950s, when Keynesian income monetarist theories began to erode and collapse, (3) the period of monetarist counter-revolution of quantitative money theory that 
overcomes Keynesian monetarist theory in parallel with monetarist theory of the assets approach until the 1960s (4) the period of harsh polarization of monetarists and nonmonetarists (Keynesians, post-Keynesians, neo-Keynesians and fiscalists) in the form of the already traditional controversy of monetarism and Keynesianism from the mid1950s to the mid-1970s, (5) the period of a new counter-revolution of Keynesians in the form of returning to original Keynes' ideas, starting from the mid-1970s and early 1980s, when monetarism, mixed with structuralism (the economy of supply), practically removed Keynesianism in creating the operational economic policies of most of the developed countries. ${ }^{5}$ The presented genesis and periodization of monetarist thought, the reclassification of monetarist theory, the differentiation of monetary analysis and the diversification of theoretical models of the monetary economy are certainly not exact, since there has never existed one dominant theory, but there have always been several socalled parallel, competitive, polarized theories. We do not strive to present the history of monetarist theory nor a detailed overview of monetarist theories, (but rather to paint a picture of the development of monetarist thought in a compressed form. From the point of view of economic theory, quantitative monetary theories are included in classical and neoclassical economic theories. Keynesian income monetary theory is an integral part of Keynesian economic theory; while modern monetary theories of property approach fall within the context of the synthesis of Keynesian and neoclassical economic theory. The classical quantitative theory incorporates the Fischer transaction variant and the income variants of Walras, Marshall, Wicksell, and Pigou, as segments of neoclassical economic theory. Keynesian income monetary theory comprises theories with different variants and various interpretations of the role of money (Hicks theory of IS-LM lines of equality of savings and investment, demand and supply of money, Samuelson, Klein, Modigliani, Clower, Dusenberry, etc.). ${ }^{6}$ Theory of the real money effect, Friedman's "monetarist counter-revolution" of reformulated quantitative money theory (with the so-called Chicago school and its representatives), which is today advocated (albeit with certain modifications) by many contemporary monetarists (Brunner, Meltzer, Cagan, Mayer , Johnson, Laidler, Anderson, Lukas, etc.) and Tobin's monetary theory (with the so-called Yale school and its supporters) underpin the contemporary trends in the development of monetary thought, which simultaneously diverges and converges in the range between Keynesianism and monetarism. (taken from: Zivkovic, Lakic, Ristic, 2019)

The monetarist direction, from the point of view of short-term observation, points out that the amount of money is the prevailing determinant of production and prices, while the Keynesian direction argues that the amount of money is no more relevant determinant than other forms of financial and real assets. However, monetarist and Keynesian theory have far more in common than monetarist theory has in common with classical quantitative theory, as well as monetarist theory of the so-called Yale school with Keynesian income monetary theory. The reason behind this lies in the fact that the Keynesian revolution did

\footnotetext{
${ }^{5}$ More in: Monetary management, Zivkovic, Lakic, Ristic, 2019.

${ }^{6}$ K. Brunner, Commentary of the State of the Monetary Debate, Federal Reserve Bank of St. Louis, Review, September 1973, pg. 14. and more in Financial acroeconomy, Ristic \& Zivkovic, 1998). As authors said: "Monetary Theories of Property Approach have basically contributed to the development of the understanding of money as a part of property and the interpretation of the operation of the amount of money on eco-movements as a process of harmonizing the scope and structure of assets with the propensity to hold assets in the form of money and other forms of property."
} 
not completely reject the quantitative theory of money, nor did the monetarist counterrevolution completely reject Keynesian income theory. Short-term aspects of observation mostly bring together monetarists and Keynesians. On the other hand, it is unjustifiable to put the monetary theory of the so-called Chicago and Yale schools of thought in the context of monetary theories of property approach because the monetary theory of the Yale school of thought embodies the Keynesian theory, and the monetary theory of the Chicago school of thought gravitates towards the pre-Keynesian quantitative money theories. In addition, the usual division of modern monetary theories into monetarism and Keynesianism, and the division of economists into monetarists and Keynesians is not precise, since the Tobin monetary theory, based on a property approach, is classified as Keynesian income monetary theory and monetarists do not accept Keynesian theory. (Ibidem, adapted form)

Empirical analyses show that the monetary policy effects do not emerge immediately and completely, but unevenly and after a certain period of time. Therefore, it is a timelag, i.e. a delayed effect of a monetary policy. There are many divisions and systematizations of timelags in the literature. Within the first form of delay, we can differentiate between the recognition lag (i.e. the time span between the moment in which monetary action is required and the moment in which the need for monetary action is required) and administrative lag (i.e. the period of time needed to adopt monetary decisions and start actions through instrumental variables of monetary policy), whereas within the second form of delay, we can make a distinction between an indirect delay or intermediate lag (i.e. the period of time between the monetary actions taken and the beginning of having effect on the money and the level of the interest rate, as variables of indirect objectives) and external delay or outside lag (i.e., a period between changing variables of indirect objectives and changing the variables of the final objectives, such as prices, employment, growth), that is, the delay in the effect generation or production lag (i.e. the interval between effected changes in expenditures and the moment they start having effect on the employment, growth and prices) and delay of decision-making or decision lag (i.e. a delay between changing the variable of the indirect objective and changing the level and structure of expenditures). (Zivkovic, Lakic, Ristic, 2019) Friedman distinguishes, inter alia, the delay in execution or implementation lag (i.e., the interval between the moment when the need for monetary action to be taken arises and the moment when the monetary action is taken) and the performance delay or operation lag (i.e. the interval between the moment the monetary policy instruments are introduced and the moment when monetary policy starts having effects on the final objectives), while other authors distinguishes the first delay or first time lag (i.e. interval between the moment the need for action arises and the actual undertaking of a monetary action) from another delay or second time lag (i.e. the time between undertaking monetary action and the effects of a monetary action on changes in the financial and the real sphere). Finally, we find that many authors differentiate between internal forms of delay i.e. inside lag encompassing recognition delay or recognition lag (i.e. the interval between the moment the need for applying monetary policy arises and the moment of taking monetary measures), the delay of the monetary action or action lag (i.e. the interval between the moment of undertaking monetary action and the moment when the banking system faces changed conditions), and external forms of delay i.e. outside lag (i.e. the interval between the functioning of the banking system in changed conditions and the moment when non-banking sectors are faced with changed money supply and loans). (Zivkovic, Lakic, Ristic, 2019) 


\section{Financial stability in light of monetarist-keynesian duels}

Keynesians basically believe that the economic sector is unstable, while monetarists claim that the economic sector is stable (provided that the unstable growth rate of the money supply does not provoke disruptions). The instability of the private sector according to Keynesians is mainly caused by changes in the marginal efficiency of investments, although in fact there are many factors that cause changes in aggregate demand. Monetarists, however, consider the total demand as a result of a stable demand for money and an unstable supply of money. According to them, the economic sector is stable because the demand for money in the sector is stable. Therefore, instability is mainly explained by the fluctuations in money supply. Consequently, the polemics of monetarists and fiscalists on the stability of the economic sector largely revolve around whether changes in the effective demand are caused by changes in money supply or changes in marginal efficiency and investment and whether the time needed to create the stability of the economic sector in the circumstances of economic disturbances. (Ristic, Zivkovic, 2018) The relationship between the stability of the economy and the quantitative money theory is not complete or solid. Namely, a fiscalist could consider the economic sector to be more stable than the analyses of the oscillations of the national product demonstrate, and therefore, could conclude that fiscal policy measures in disrupted conditions record the destabilizing effects in the same way that the monetary policy does not lead to stabilization in the given conditions. Such a position is not in contradiction to the basic settings of fiscalism, or Keynesian theory. In that case, an economist can believe that the economic sector is more stable, although he is not a monetarist by his or her conviction. However, it is simply impossible to persuade a monetarist in the Keynesians' stance on the instability of the economic sector.

Keynesian models, according to Brunner, emphasize the instability of the corporate sector and reject the hypothesis about the natural rate. Implications of the fundamental instability of the economic sector are determined by the activist and interventionist concept of fiscal policy, since the public sector is inevitably the "ultimate stabilizer". Therefore, in various textbook versions of the Keynesian analysis, it is claimed that the estimates of economic trends in the short run mostly depend on the movement and changes in fiscal variables and the dominant role is bestowed on fiscal policy. (interested analysis in paper of Richard and Penny Musgrave in period 1992-1997). In econometric models, an influential monetarist does not support the Keynesian thesis on the instability of the private sector, on the contrary, the sector's stability is empirically described, as well as its ability to absorb disruptions and to self-stabilize. The instability of the private sector is mainly caused by public sector measures. The supporters of the natural rate hypothesis and stability hypothesis, as a rule, deny the viewpoints of "public interest" to stabilize the real public sector and point out that the fluctuations of real variables depend on monetary impulses. However, the hypothesis of the "dominant impulse" is already being challenged and negated by emphasizing systemic combination of alternative impulses.

Brunner - Meltser's analysis of the combined monetary and fiscal policy emphasizes the role of fiscal policy and the behaviour of the public sector. Tobin argued that autonomous changes in demand and supply of different types of financial assets limit the impulses that affect the level of production and price levels. However, Tobin's conclusion on the possibility of unstable demand for money, which, as a doctrine, has 
replaced the concept of free reserves, negates the empirical work of monetarists, who deny the thesis of instability. From the point of view of the inclusion of "cost inflation" in the analysis, the problem of impulse and stability further complicates, since different points of view lead to alternative interpretation of price and wage movements. In this context, the movement of prices and wages depends on the market situation (theory of prices stance), that is, the functioning of the autonomous powers (the standpoint of the institutional frameworks and sociological factors). According to the first point of view, the movement of prices and wages is under the influence of the transmission mechanism, whereby the decelerations in the circumstances of inherited inflation lead simultaneously to a rise in prices, an increase in unemployment and a delay in production. According to the second point of view, the movement of prices and wages does not respond to the market conditions, but to the changes in the institutional frameworks and sociological factors that are outside the framework of the response patterns given in the theory of prices from the point of view of cost inflation. While creating the theory of cost-based inflation and unemployment, Gordon empirically proved that costs are independent from changes in the market conditions and the expected policy direction. The cost factor fully autonomously determines wages, unemployment and prices, although prices and wages systematically react.

The private sector stability hypothesis, is an essential determinant of monetarism, which is welcomed by all monetarists (Mayer, Friedman, Brunner, Meltzer), since monetarists generally believe in the inherent stability of the economic sector, provided that it is left to itself and protected against irregular monetary growth. Monetarist theory is fundamentally different from Keynesianism because monetarists believe that the economic system shows a tendency to converge towards the equilibrium of its real variables. (Zivkovic, Kozetinac, Popovic, 2019) Lending expansion, which induces an increase in money supply, affects the reduction of the market interest rate in comparison with the natural interest rate at the given equilibrium between voluntary savings and planned investments. Issuing money through bond loans for the purchase of investment goods induces inflationary effects and changes in the real sector (through the rise in relative prices of investment goods in relation to consumption goods, over-demand in the labour market trends, declining production of consumer goods and the increase in monetary wages). If the propensity to savings at the point of an expansionary process (in which the market interest rate begins to rise) does not show a tendency to grow, then additional money issuing is required (accelerating the expansion of the money offer), or permanent money issuing at a rising rate in order to maintain the cumulative process.

\section{Conclusion}

The theoretical and empirical experiment with monetarism, neoclassicism and economics of the supply, has apparently helped us regain some faith in the Keynesian recipe (theory), but not in the old-fashioned Keynesianism of the 1960s. Rehabilitation of the Keynesian economics is therefore increasingly attractive due to the lack of theoretical fundamentals of monetarism, the empirical bases of the theory of rational expectations and the theoretical-empirical evidence of supply-siders. On the other hand, the Keynesian renaissance at the beginning of the 1980s is the result of the fact that 
each of the "new" theories left its own mark on Keynesianism. The latest financial crisis testifies to this. Modern Keynesianism has therefore begun to emphasize the importance of monetary policy, to include rational expectations as a working hypothesis and to respect the significance of the supply. Nevertheless, in terms of these macroeconomic reinterpretations, it is premature to claim that the complete rehabilitation of the Keynesian economics is on the horizon. The aim of this paper is not an attempt to synthesize Keynesianism and monetarism, but rather to present the convergent and divergent theoretical stances by exploring and examining the range of earlier empirics, and to expose the settings explained in opposing discussions and controversies, and present the parallel theories of Keynesianism and monetarism on key macroeconomic indicators. In this regard, the catalogue of elaborations presented in this paper can be used as a basis for further methodological rethinking of tendencies in monetary analysis and macroeconomic policy.

\section{Bibliography}

Brunner. K., \& Meltzer Allan H. (1997). (1) Money abd the Economy: Issues in monetary analysis. New York, Press Sindicateof the University of Cambridge.

Brunner K. (1968). (3) The Role of Money and Monetary Policy. Federal Reserve Bank of St. Louis, Review.

Cencini A. (1997). (2) Monetary theory. New York, Mackays of Chatman PLC.

Friedman M. (1968). (3) The Role of Monetary Policy. American Economic Review.

Knežević, S., Mitrović, A., \& Sretić, D. [2018]. Specifics of reporting on cash flows in insurance companies. Menadžment u hotelijerstvu i turizmu, 6(2), 21-33.

Lukić, V., \& Živković, A. (2018). The consequences of digital revolution in monetary realm. Anali Ekonomskog fakulteta u Subotici, (39), 157-170.

Mayer T. (1977). (3) The Structure of Monetarism. Duncher und Humblot.

Petrović, P., \& Živković, A. (2015). The monetary policy and cheap money. Anali Ekonomskog fakulteta u Subotici, (33), 237-245.

Ristic Z., \& Zivkovic A. (1998). (5) Financial macroeconomy. Belgrade, Cigoja.

Smithin J. (2003). (1) Controversies in monetary economics. Massachusetts USA, Edward Elgar Publishing Limited.

Šoškić, D. (2015). Inflation impact of food prices: Case of Serbia. Ekonomika poljoprivrede, 62(1), 41-51.

Tobin J. (1972). (3) Inflation and Unemployment. American Economic Review.

Zivkovic, A., Kozetinac, G., \& Popovic, S. (2019). (1) Monetary economy. Belgrade. Faculty of economics.

Zivkovic, A., Lakic, S., \& Ristic, K. (2019). (4) Monetary management. Belgrade. Faculty of economics. 